\title{
GEJALA PERGESERAN MINAT BERWIRAUSAHA ANAK MUDA DI YOGYAKARTA DITINJAU DARI ASPEK KREATIVITAS \\ DAN MOTIVASI
}

\author{
Wisnu Hadi \\ Dosen Akademi Pariwisata Bina Sarana \\ Informatika Yogyakarta \\ email : wisnu.wsh@bsi.ac.id
}

Oleh

Atun Yulianto
Dosen Akademi Pariwisata Bina Sarana
Informatika Yogyakarta
email : atun.aty@bsi.ac.id

\section{ABSTRACT}

This study aims to determine the effect of the symptoms of the entrepreneurial aspects of the shift of interest in terms of the aspect of creativity of young people, the interest in entrepreneurship in young people aspects of motivation and interest berwirauaha together with aspects of creativity and motivation of young people in the region involves Yogyakarta.

Research 100 young people as respondents who have business in the area of Yogyakarta. Sampling was done by proportional random sampling technique with 75 young people. This study uses a design ex-post facto. Data were collected using questionnaires and documentation. Data were analyzed using correlation analysis.

Base on these results it can be concluded that: first there is the contribution of interest in entrepreneurship with creativity aspects of youth entrepreneurship in the region of Yogyakarta, the second is the contribution of interest in entrepreneurship with motivational aspects of entrepreneurship, the third is the collective contribution of common interest in entrepreneurship with aspects of creativity and motivation of youth entrepreneurship in the region of Yogyakarta.

Keywords: interest, creativity, entrepreneurial motivation,

\section{LATAR BELAKANG MASALAH}

Permasalahan bangsa Indonesia saat ini begitu kompleks, hampir dari semua aspek kehidupan menjadi masalah nasional. Tidak hanya bidang sosial ekonomi saja, namun politik dan agama juga sudah mulai mencuat, hal ini ditandai dengan banyaknya aksi-aksi demontrasi yang menimbulkan perselisihan antar beberapa kelompok dalam masyarakat. Suasana yang tidak kondusif ini berakibat krisis dibidang ekonomi berkepanjangan, meningkatnya jumlah pengangguran dan tindak kejahatan dan akhirnya mengakibatkan semakin rumitnya penyelesaian dari masalah nasional ini. Jumlah pengangguran dari tahun ke tahun terus meningkat, hal ini disebabkan sedikitnya lapangan pekerjaan sedangkan jumlah lulusan sekolah atau perguruan tinggi terus bertambah.

Akibat dariituterjadiketidakseimbangan antara jumlah lapangan pekerjaan dengan orang yang akan bekerja. Apalagi diperparah dengan timbulnya aksi PHK dari beberapa perusahaan yang mengalami kebangkrutan. Masalah pengangguran sebenarnya bisa diatasi jikalau negara mampu menyediakan lapangan pekerjaan sebanyak mungkin. Namun hal ini sepertinya tidak mungkin bisa secepatnya terealisasi, karena banyaknya kendala baik dari segi ekonomi maupun sumber daya manusia (SDM) itu sendiri. 
Dalam usaha mewujudkan calon-calon pengusaha muda yang terdidik, kuliah kewirausahaan (KWU) di lingkungan sekolah atau kampus merupakan salah satu program awal yang dapat ditempuh oleh siswa atau mahasiswa untuk membekali diri dalam bidang kewirausahaan..

Faktor Minat dan kreativitas siswa atau mahasiswa merupakan hal yang dapat mempengaruhi motivasi untuk berwirausaha. Adanya gejala trend berwirausaha dikalangan muda sekarang dimana mereka mempunyai orientasi pasar ke depan ditunjang dengan teknologi yang modern sehingga membantu mereka membuka usaha atau sedang yang merintis usaha. Dengan demikian untuk mengetahui sejauh mana minat dan kreativitas dapat mempengaruhi motivasi untuk berwirausaha pada siswa sekolah khusunya anak muda di wilayah Yogyakarta.

Sebagai kota pendidikan dan budaya Yogyakarta selalu dikunjungi wisatawan domestik dan asing yang ingin berlibur, tentunya ini menjadi peluang anak muda atau warga untuk menciptakan sesuatu yang akan menghasilkan uang. Peran Pemerintah Daerah dalam hal ini Pemerintah Kota dan Kabupaten di DIY sangat luar biasa dalam hal ini memberikan fasilatas modal dan sarana-prasarana, juga pemikiran. Sekarang jika kita berkeliling di wilayah Yogyakarta banyak usaha-usaha yang baru atau lama yang menarik konsumen atau pembeli untuk membeli produk yang mereka tawarkan. Usaha-usaha yang didominasi anak muda ini ternyata ampuh menarik wisatawan untuk membelinya. Untuk ini penulis melakukan penelitian tentang hubungan bersama tentang gejala anak muda yang berminat untuk berminat berwirausaha ditinjau dari aspek kreativitas dan motivasi berwirausaha di wilayah Yogyakarta.

Penelitian ini dilaksanakan di wilayah Yogyakarta dengan sasaran objek penelitiannya anak muda yang mempunyai usaha atau merintis usaha disegala bidang.
Metode yang digunakan dalam penyusunan penelitian ini adalah metode deskriptif yang dirancang untuk mengumpulkan informasi tentang keadaan-keadaan nyata sekarang (sementara berlangsung). Untuk mengumpulkan data yang diperlukan, maka penulis menggunakan Kuesioner.

Tujuannya dari penelitian ini adalah untuk mengetahui hubungan bersama antara gejala pergeseran minat berwirausaha ditinjau dari aspek kreativitas dan aspek motivasi anak muda di wilayah Yogyakarta. Sehingga akhir dalam penelitian ini adakah hubungan antara aspek minat berwirausaha ditinjau dari aspek kreativitas dan aspek motivasi anak muda di wilayah Yogyakarta

\section{LANDASAN TEORI}

\section{Kreativitas}

Kreativitas adalah melihat hal-hal yang juga dilihat orang lain di sekitar kita, tetapi membuat keterkaitan-keterkaitan yang tak terpikir oleh orang lain. Orang yang kreatif membawa makna atau tujuan baru dalam suatu tugas, menemukan penggunaan baru, menyelesaikan masalah, atau memberikan nilai tambah atau keindahan (Wycof, 2005).

Memecahkan masalah dan kreativitas merupakan hasil dari kecerdasan tingkat tinggi. Kemampuan tersebut akan terbentuk ketika seseorang memiliki basis konsep dan prinsip yang diperlukan. Kreativitas telah ditentukan dalam beberapa cara. Setiap orang kreatif, namun hanya sedikit yang mampu menghasilkan sesuatu yang berbeda. Untuk menentukan kreativitas seseorang, sangat jelas bahwa kecerdasan dan kreativitas tidak identik, walaupun banyak orang pintar yang juga kreatif. Menurut Wycof (2005) orang yang kreatif memiliki ciri-ciri sebagai berikut:

a. Keberanian, Orang yang kreatif berani menghadapi tantangan baru dan bersedia menghadapi kegagalan. 
b. Ekspresif. Orang kreatif tidak takut menyatakan pemikiran dan perasaannya.

c. Humor. Humor berkaitan erat dengan kreativitas. Jika kita menggabungkan halhal sedemikian rupa sehingga menjadi berbeda, tak terduga dan tidak lazim, berarti kita bermain dengan humor

d. Intuisi. Orang kreatif menerima intuisi sebagai aspek wajar dalam kepribadiannya. Mereka paham bahwa intuisi umumnya berasal dari otak kanan yang memiliki pola komunikasi berbeda dengan belahan otak kiri.

\section{Motivasi}

Motivasi merupakan kekuatan yang mendorong seseorang melakukan sesuatu untuk mencapai tujuan. Kekuatan-kekuatan yang mendorong seseorang untuk melakukan sesuatu pada dasarnya dirangsang oleh adanya berbagai macam kebutuhan dan atau keinginan yang hendak dipenuhinya. (Tabrani 1992).

Menurut Bimo Walgito motivasi adalah sesuatu kekuatan yang terdapat dalam individu yang menyebabkan individu itu bertindak atau berbuat, dorngan ini terjadi karena tertuju pada suatu tujuan tertentu dan berkembang atas dasar individu dalam masyarakat.

MenurutA.Hilgardmotivasiadalah suatu keadaan dalam individu yang menyebabkan seseorang melakukan kegiatan mencapai tujuan tertentu (Pasaribu Simanjuntak, 1984). Supardi dan Anwar (2004) motivasi adalah keadaan dalam pribadi seseorang yang mendorong keinginan individu untuk melakukan kegiatan-kegiatan tertentu guna mencapai tujuan. Motivasi yang ada pada seseorang akan mewujudkan suatu perilaku yang diarahkan pada tujuan mencapai sasaran kepuasan, motivasi bukanlah yang dapat diamati tetapi adalah hal yang dapat disimpulkan adanya karena sesuatu perilaku yang tampak.
Menurut Heidjachaman dan Husnan (2003), motivasi adalah merupakan proses untuk mencoba mempengaruhi seseorang agar melakukan sesuatu yang kita inginkan. Juga pendapat lain menurut As'ad motivasi sering diartikan dengan istilah dorongan atau tebaga tersebut merupakan gerak jiwa dan jasmani untuk berbuat sehingga motivasi tersebut merupakan driving force yang mengerakan manusia untuk bertingkah laku dan didalam perbuatannya itu mempunyai tujuan tertentu.

\section{Minat}

Minat merupakan faktor psikologis yang dapat menentukan suatuz pilihan pada seseorang, selain itu minat merupakan salah satu faktor psikologis yang sangat penting untuk kemajuan dan keberhasilan seseorang. Seseorang yang mengerjakan suatu pekerjaan disertai minat sebelumnya, pada umumnya akan memperoleh hasil yang lebih baik dari pada mereka yang tidak berminat sebelumnya.

Menurut W.S Winkel (2004) minat adalah kecenderungan yang agak menetap dalam subjek untuk merasa tertarik pada bidang atau hal tertentu dan merasa senang berkecimpung dalam bidang tersebut. Pada dasarnya seseorang yang mempunyai minat yang tinggi akan mencapai hasil yang maksimal. Hal tersebut disebabkan oleh faktor-faktor yang mempengaruhi minat. Faktor-faktor yang mempengaruhi minat dikelompokkan menjadi dua golongan (Winkel, 2004):

1. Sebab endogen (dari dalam diri sendiri) : (a) Biologis, misalnya kesehatan, cacat badan, (b) Psikologis, misalnya kecerdasan, minat.

2. Sebab eksogen (dari luar diri sendiri) : (a) Keluarga, yaitu faktor orang tua, suasana rumah, (b) Faktor sekolah, masyarakat

\section{Wirausaha}


Arti kata wirausaha yaitu wira = utama, gagah, luhur, berani, teladan; swa = sendiri; sta $=$ berdiri; $u s a h a=$ berdiri atas kemampuan sendiri. Berdasarkan arti kata tersebut maka wirausaha berarti sifat-sifat keberanian, keutamaan, dan keteladanan dalam mengambil resiko yang bersumber pada kemampuan sendiri (Wiratmo, 1995).

Kewirausahaan secara lebih luas didefinisikan sebagai proses penciptaan sesuatu yang berbeda nilainya dengan menggunakan usaha dan waktu yang diperlukan, memikul resiko finansial, psikologis, dan sosial yang menyertainya, serta menerima balas jasa moneter dan kepuasan pribadi. Orang yang memulai dan mengerjakan usahanya sendiri, mengorganisasi dan membangun perusahaan sejak revolusi industri dinamakan kewirausahaan (Wiratmo, 1995).

Di dalam kewirausahaan, disepakati adanya tiga jenis perilaku, yaitu: memulai inisiatif, mengorganisasi dan mereorganisasi mekanisme sosial atau ekonomi untuk mengubah sumber daya dan situasi dengan cara praktis, diterima resiko atau kegagalan.

\section{METODE PENELITIAN}

Dalam penelitian ini peneliti menggunakan metode deskriptif (kualitatif) yang dirancang untuk mengumpulkan informasi tentang keadaan-keadaan nyata sekarang (sementara berlangsung). Tujuan utama dalam menggunakan metode ini adalah untuk membuat deskriptif tentang gambaran secara sistematis, faktual dan akurat mengenai fakta-fakta, sifat-sifat serta hubungan fenomena yang diselidiki.

Dalam penelitian ini teknik pengambilan data dilakukan dengan cara angket atau kuesioner bagi anak muda yang sedang merintis usaha atau sudah mempunyai usaha berjalan diwilayah Yogyakarta khususnya diwilayah utara Yogyakarta dan selatan Yogyakarta. Dimana nanti kita ambil 25\% dari keseluruhan populasi yang berjumlah
100 anak muda dan peneliti mengambil sampel sebanyak 75 anak muda yang mempunyai usaha.

Sehubungandenganpengambilansampel yang representatif peneliti berpedoman pada pendapat Suharsimi Arikunto (2006) yang menyatakan: "Untuk sekedar ancerancer, maka apabila subyeknya kurang dari 100 lebih baik diambil semua sehingga penelitiannya merupakan penelitian populasi. Tetapi, jika jumlah subyeknya besar, dapat diambil antara $10-15 \%$ atau $20-25 \%$ atau lebih. Teknik analisis data yang digunakan dalam penelitian ini akan digunakan dalam menguji besarnya pengaruh dan kontribusi variable X1, dan X2 terhadap Y. Analisis data ini untuk mengetahui kreativitas anak muda (X1), dan motivasi anak muda (X2) secara bersama-sama berkontribusi secara signifikan terhadap minat anak muda dalam berwirausaha (Y) di kalangan anak muda di wilayah Yogyakarta, baik secara bersamasama maupun secara individu.

\section{HASIL DAN PEMBAHASAN}

\section{Diskripsi Responden}

Penelitian ini menggunakan metode deskriptif dengan pendekatan korelasional. Populasi dalam penelitian ini adalah anak muda yang mempunyai usaha yang sedang dirintis atau sudah berjalan dengan jumlah populasi 100 orang dengan perhitungan sampel didapatkan 75 orang sebagai responden. Pengambilan data dilakukan pada bulan Juli-Agustus 2014. Jenis kelamin responden terdiri dari jumlah kelamin laki-laki 51 orang dan perempuan 24. Berdasarkan usia responden dapat diperolah data sebagai berikut :

Tabel 1 : Usia Responden

\begin{tabular}{|c|c|}
\hline Umur & $\begin{array}{c}\text { Jumlah } \\
\text { Responden }\end{array}$ \\
\hline $15-20$ tahun & 16 \\
\hline $21-25$ tahun & 44 \\
\hline $25-30$ tahun & 15 \\
\hline
\end{tabular}




\begin{tabular}{|c|c|}
\hline$>30$ tahun & 0 \\
\hline Jumlah & 75 \\
\hline
\end{tabular}

\section{Hasil Analisis Data}

Uji Kelayakan Variabel

\section{Uji Normalitas}

Uji normalitas dilakukan dengan olah data menggunakan program SPSS Statistik 17 untuk mengetahui normal tidaknya data dengan melihat sebaran titik-titik data disekitar garis diagonal. Hasil uji normalitas data dapat dilihat pada gambar-gambar dibawah ini :

\section{Normal P-P Plot of Regression Standardized
Residual}

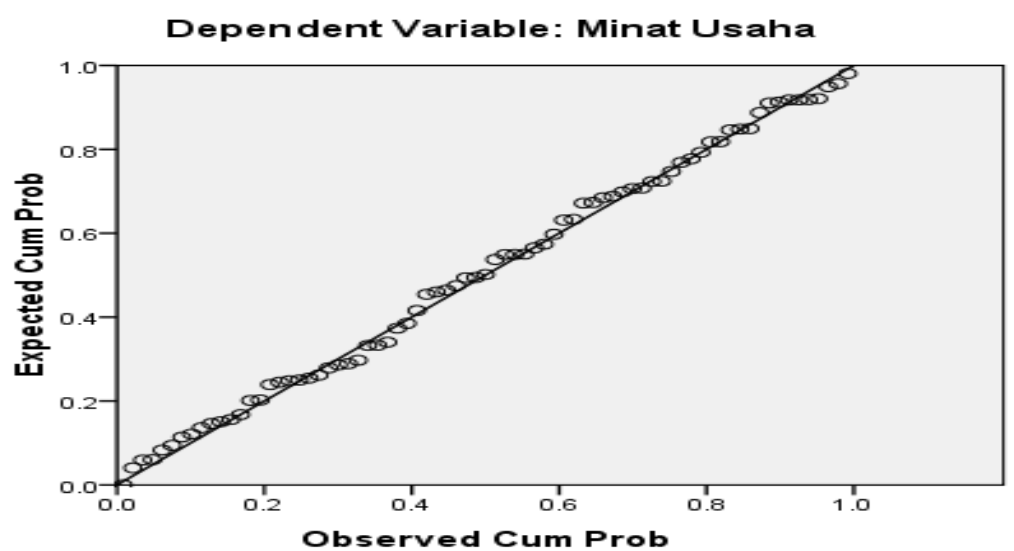

Gambar 1 Grafik Normalitas Data

Dari gambar diatas dapat disimpulkan bahwa uji regresi liner berganda dapat dilakukan. Dengan alasan bahwa gambar sudah menunjukkan penyebaran data dalam tanda titik-titik disekitar garis diagonal dan mengikuti arah garis diagonal, hal tersebut menunjukkan data sudah normal.

\section{Uji Heteroskedastisitas}

Adapun hasil pengujian heteroskedastisitas menggunakan analisis grafik dengan bantuan program SPSS 17 dapat dilihat pada gambar berikut ini:

Scatterplot

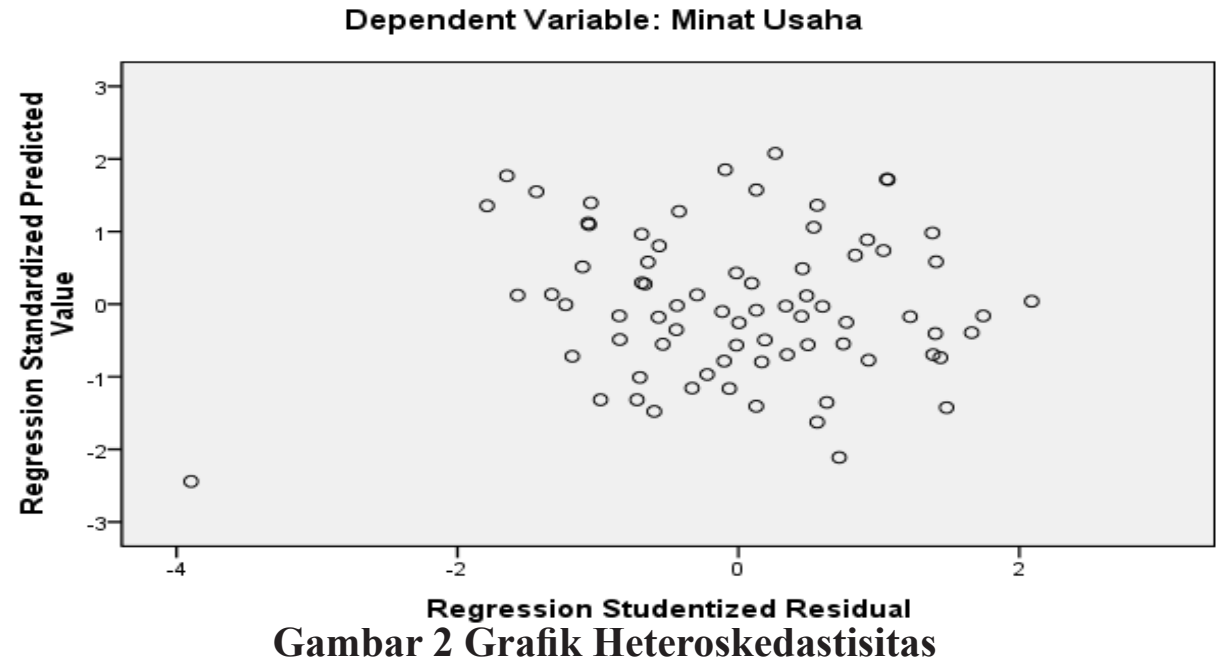


Dari gambar 5.2 diatas terlihat bahwa titik-titik menyebar diatas dan dibawah angka 0 pada sumbu Y, maka dalam hal ini persamaaan regresi terbebas dari asumsi adanya heteroskedastisitas

\section{Analisis Regresi Linier Berganda}

Hasil olah data statistik dengan menggunakan SPSS 17 menghasilkan persamaan regresi linier berganda yang digunakan untuk mengetahui bentuk hubungan antara variabel bebas dan terikat dengan mengambil data tabel sebagai berikut

Tabel 2 Koefisien Persamaan Regresi

\begin{tabular}{|c|c|c|c|c|c|c|}
\hline \multicolumn{2}{|c|}{ Model } & \multicolumn{2}{|c|}{ Unstandardized Coefficients } & $\begin{array}{c}\text { Standardized } \\
\text { Coefficients }\end{array}$ & $\mathrm{t}$ & Sig. \\
\hline \multicolumn{2}{|c|}{1} & B & Std. Error & Beta & & \\
\hline \multirow{4}{*}{1} & (Constant) & 19.387 & 5.070 & & 3.824 & .000 \\
\cline { 2 - 7 } & Kreativitas & .214 & .166 & .140 & 1.291 & .201 \\
\cline { 2 - 7 } & Motivasi & .233 & .047 & .531 & 4.910 & .000 \\
\hline
\end{tabular}

a. Dependent Variable: Minat Usaha

$$
Y=19.387+0.214 X_{1}+0.233 X_{2}
$$

Dari persamaan diatas maka dapat diinterpretasikan sebagai berikut :

a. Konstanta (b) $=19.387$, berarti bahwa minat usaha sebesar 19.387satuan jika tidak ada pengaruh dari variabel kreativitas $\left(\mathrm{X}_{1}\right)$ dan motivasi $\left(\mathrm{X}_{2}\right)$.

b. Koefisien regresi $X_{1}=0.214$, artinya minat usaha akan meningkat sebesar 0.214 satuan untuk setiap tambahan satu satuan variabel kreativitas dengan asumsi variable yang lainnya dianggap konstan.

c. Koefisien regresi $\mathrm{X}_{2}=0.233$, artinya minat usaha akan meningkat sebesar 0.233 satuan untuk setiap tambahan satu satuan variabel motivasi dengan asumsi variable yang lainnya dianggap konstan.

Berdasarkan data-data tabel di atas, dapat disimpulkan bahwa kreativitas $\left(\mathrm{X}_{1}\right)$ tidak berpengaruh secara parsial terhadap minat usaha, ditunjukkan dengan nilai signifikansi, 0,2. Sedangkan variabel motivasi (X2), berpengaruh secara parsial terhadap minat usaha, ditunjukkan dengan nilai signifikansi 0,00 , yakni dibawah 0,05

\section{Uji t ( t test)}

Uji t dapat dinyatakan dengan persyaratan :

a. jika $\mathrm{t}_{\text {hitung }}>\mathrm{t}_{\text {tabel }}$ atau $-\mathrm{t}_{\text {hitung }}<-\mathrm{t}_{\text {tabel }}$ maka hasilnya signifikan dan berarti $\mathrm{HO}$ ditolak dan $\mathrm{H} 1$ diterima.

b. jika $\mathrm{t}_{\text {hitung }}<\mathrm{t}_{\text {tabel }}$ atau $-\mathrm{t}_{\text {hitung }}>-\mathrm{t}_{\text {tabel }}$ maka hasilnya tidak signifikan dan berarti $\mathrm{H}_{0}$ diteima dan $\mathrm{H}_{1}$ ditolak.

Dengan bantuan program SPSS 17 didapatkan hasil olah data regresi dengan nilai $\mathrm{t}$ hitung seperti disajikan pada tabel dibawah ini :

Tabel 3 Uji Regresi Secara Parsial

\begin{tabular}{|l|c|c|c|c|c|c|}
\hline \multicolumn{2}{|c|}{ Model } & \multicolumn{2}{|c|}{ Unstandardized Coefficients } & $\begin{array}{c}\text { Standardized } \\
\text { Coefficients }\end{array}$ & \multirow{2}{*}{$\mathrm{t}$} & \multirow{2}{*}{ Sig. } \\
\cline { 3 - 5 } \multicolumn{2}{|c|}{1} & B & Std. Error & Beta & & \\
\hline \multirow{3}{*}{1} & (Constant) & 19.387 & 5.070 & & 3.824 & .000 \\
\cline { 2 - 7 } & Kreativitas & .214 & .166 & .140 & 1.291 & .201 \\
\cline { 2 - 7 } & Motivasi & .233 & .047 & .531 & 4.910 & .000 \\
\hline
\end{tabular}

a. Dependent Variable: Minat Usaha 
Berdasarkan tabel diatas dapat diperoleh hasil uji t sebagai berikut :

a. $\mathrm{t}$ test antara kreativitas $\left(\mathrm{X}_{1}\right)$ dengan minat usaha $(\mathrm{Y})$ menunjukkan $\mathrm{t}_{\text {hitung }}=$ 1.291. Sedangkan $\mathrm{t}_{\text {tabel }}(\alpha=0.05 ; \mathrm{df}=$ 73) adalah sebesar 1.667. Maka karena $\mathrm{t}$ hitung $<\mathrm{t}$ tabel yaitu $1.291<1.667$, hal ini berarti $\mathrm{H}_{0}$ diterima dan $\mathrm{H}_{1}$ ditolak. Berdasarkan perbandingan tersebut tidak terdapat pengaruh secara parsial anatara kreativitas terhadap minat usaha.

b. $t$ test antara motivasi $\left(\mathrm{X}_{2}\right)$ dengan minat usaha $(\mathrm{Y})$ menunjukkan $\mathrm{t}_{\text {hitung }}=4.910$. Sedangkan $t_{\text {tabel }}(\alpha=0.05 ; \mathrm{df}=73)$ adalah sebesar 1.667. Maka karena $t_{\text {hitung }}>$ $\mathrm{t}$ tabel yaitu 4.910> 1.667, hal ini berarti $\mathrm{H}_{0}$ ditolak dan $\mathrm{H}_{1}$ diterima. Berdasarkan perbandingan tersebut terdapat pengaruh secara parsial antara motivasi terhadap minat usaha.

\section{Uji F (F test)}

Uji $F$ dapat dilakukan dengan membandingkan statistik hitung dengan statistik tabel dengan persyaratan :

1. Jika $\mathrm{f}_{\text {hitung }}>\mathrm{f}_{\text {tabel }}(\alpha=0.05)$, maka hasilnya signifikan sehingga Ho ditolak dan $\mathrm{H}_{1}$ diterima

2. Jika $\mathrm{f}_{\text {hitung }}<\mathrm{f}_{\text {tabel }}(\alpha=0.05)$, maka hasilnya signifikan Ho diterima dan $\mathrm{H}_{1}$ ditolak

Nilai $F_{\text {hitung }}$ diperoleh memlalui olah data dengan menggunakan bantuan program SPSS 17 yang disajikan pada tabel dibawah ini :

Tabel Uji 4 Regresi Secara Simultan

\begin{tabular}{|l|l|r|r|r|r|r|}
\hline \multicolumn{2}{|c|}{ Model } & Sum of Squares & df & Mean Square & F & Sig. \\
\hline 1 & Regression & 674.654 & 2 & 337.327 & 21.860 & $.000^{\mathrm{a}}$ \\
\cline { 2 - 7 } & Residual & 1111.026 & 72 & 15.431 & & \\
\cline { 2 - 7 } & Total & 1785.680 & 74 & & & \\
\hline
\end{tabular}

Berdasarkan Tabel diketahui nilai $F$ usaha hitung sebesar 21.860. Sedangkan $F_{\text {tabel }}(\alpha=$ 0.05 ) adalah sebesar 3.12. Maka karena $F$ hitung $>\mathrm{F}_{\text {tabel }}$ yaitu 21.860>3.12, hal ini berarti $\mathrm{H}_{0}$ ditolak dan $\mathrm{H}_{1}$ diterima. Berdasarkan perbandingan tersebut terdapat pengaruh secara simultan (bersama) antara variable kreativitas dan motivasi terhadap minat

\section{Uji Koefisien Determinsi (R2)}

Hasil pengujian koefisien determinasi dalam penelitian ini dilakukan dengan menggunakan bantuan program SPSS 17 dengan hasil seperti pada tabel berikut ini :

Tabel Uji 4 Regresi Secara Simultan

\begin{tabular}{|l|l|r|r|r|r|r|}
\hline \multicolumn{2}{|c|}{ Model } & Sum of Squares & df & Mean Square & F & Sig. \\
\hline \multirow{3}{*}{1} & Regression & 674.654 & 2 & 337.327 & 21.860 & $.000^{\mathrm{a}}$ \\
\cline { 2 - 7 } & Residual & 1111.026 & 72 & 15.431 & & \\
\cline { 2 - 7 } & Total & 1785.680 & 74 & & & \\
\hline
\end{tabular}

Koefisien determinasi digunakan Dari analisis pada Tabel diperoleh hasil untuk menghitung besarnya kontribusi $\mathrm{R}^{2}$ (koefisien determinasi) sebesar 0.378 , variabel bebas terhadap variabel terikat. artinya kemampuan variabel bebas $\mathrm{X}_{1}$ dan 
$\mathrm{X}_{2}$ dalam menjelaskan variabel terikat $\mathrm{Y}$ adalah sebesar $37.88 \%$, sedangkan sisanya, yakni $62,2 \%$ akan dijelaskan oleh variabel independen lain yang tidak termasuk dalam penelitian ini

\section{PEMBAHASAN}

Dalam penelitian ini bertujuan untuk mengetahui apakah ada pengaruh motivasi dan kreativitas berwirausaha terhadap minat berwirausaha bagi anak muda di wilayah Yogyakarta. Untuk itu hasil penelitian dapat kami jelaskan sebagai berikut :

\section{Pengaruh Variabel kreativitas $\left(X_{1}\right)$ Terhadap minat usaha (Y)}

Dengan regresi linear sederhana diperoleh hasil bahwa kreativitas berwirausaha berpengaruh terhadap minat usaha dengan nilai koefisien sebesar 0,214. Dan mempunyai korelasi kuat dengan nilai koefisien korelasi sebesar 0,140. Data ini menunjukkan bahwa kreativitas berwirausaha yang dimiliki oleh anak muda Yogyakarta sangat berpengaruh kuat pada minat usaha yaitu para anak muda yang mempunyai usaha. Selain itu juga kreativitas mereka mempunyai pengaruh yang signifikan atau mempunyai hubungan yang signifikan terhadap minat usaha untuk membuka usaha di wilayah Yogyakarta.

Dari hasil pengolahan data, diketahui bahwa variabel motivasi berwirausaha berpengaruh terhadap minat usaha baik secara individu maupun bersamaan dengan variabel kreativitas usaha dikalangan anak muda di seputaran Yogyakarta. Hal ini berdasarkan data-data tabel diatas bahwa kreativitas dan motivasi berpengaruh positif terhadap minat usaha anak muda membuka usaha di wilayah Yogyakarta. Selain itu dari hasil penelitian bahwa variabel kreativitas berwirausaha bahwa anak muda yang berminat dibidang usahanya ingin sesuatu yang baru artinya mereka berpikir kreatif yang menghasilkan uang meski itu bukan keahliannya dan itu ditemukan pada responden sejumlah $70,7 \%$. Dari data yang sama dengan jumlah $70,7 \%$ yang setuju mereka ingin mempraktekkan materi yang diperoleh dari kegiatan usahanya. Dengan demikian mereka yang terjun diusaha ingin mempelajari hal-hal yang baru karena mayoritas kurang lebih 50,7\% selalu tertarik terhadap hal-hal yang baru.

Dari hasil penelitian tentang kreativitas usaha bahwa bisa anak muda yang tertarik dengan minat usaha diwilayah Yogyakarta sangat tinggi artinya penemuan data yang diperoleh selama penelitian bahwa anak muda selalu memanfaatkan waktu senggang untuk melakukan kegiatan yang bermanfaat. Ini sesuai dengan teori yang dikemukan oleh Zimmerer yang disadur oleh Buchari Alma (2007) bahwa kreativitas adalah kemampuan untuk mengembangkan ide baru dan menemukan cara baru dalam melihat peluang ataupun problem yang dihadapi. Dengan ini seorang usahawan yang dilakukan oleh anak muda di Yogyakarta akan berhasil jika ia selalu kreatif, dan menggunakan hasil kreativitas itu dalam kegiatan usahanya. Dan tentunya jika itu digunakan namun jika kreativitas tidak digunakan maka tidak ada nilainya.

\section{Pengaruh Variabel motivasi (X2) Terhadap minat usaha (Y)}

Dengan regresi linear sederhana diperoleh hasil bahwa motivasi berwirausaha berpengaruh terhadap minat berwirausaha dengan nilai koefisien sebesar 0,233. Dan mempunyai korelasi kuat dengan nilai koefisien korelasi sebesar 0,531. Data ini menunjukkan bahwa motivasi berwirausaha yang dimiliki oleh anak muda Yogyakarta sangat berpengaruh kuat pada minat usaha yaitu para anak muda yang mempunyai usaha yang sesuai dengan kreativitas dirinya. Selain itu juga motivasi usaha mereka mempunyai pengaruh yang signifikan atau mempunyai hubungan yang signifikan terhadap minat usaha untuk membuka usaha 
di wilayah Yogyakarta artinya dorongan anak muda untuk membuka usaha sangat kuat karena kreativitas yang menjadi modal mereka untuk berani membuka usaha.

Dari hasil pengolahan data, diketahui bahwa variabel motivasi berwirausaha berpengaruh terhadap minat usaha baik secara individu maupun bersamaan dengan variabel kreativitas usaha dikalangan anak muda di seputaran Yogyakarta. Hal ini berdasarkan data-data tabel diatas bahwa kreativitas dan motivasi berpengaruh positif terhadap minat usaha anak muda membuka usaha di wilayah Yogyakarta dengan pendapat ini tentunya menjadi kesimpulan bahwa ke dua variabel antara motivasi dan kreativitas usaha sangat berkaitan dan tentunya akan berpengaruh terhadap minat usaha.

Selain itu dari hasil penelitian bahwa variabel motivasi berwirausaha dari frekuensi butir -butir pernyataan yang dijawab responden bahwa dengan berwirausaha akan selalu menguntungkan dan dijawab sejumlah 54,7\%. Dan mereka ingin berwirausaha karena cita-cita sesuai dengan studinya dijawab sebesar $37,3 \%$. Dari penelitian yang saya sebarkan quesioner ternyata berwirausaha atau memiliki bisnis lebih membahagiakan daripada menjadi karyawan dijawab oleh 41,3\% dan menjadikan bisnis sebagai hal prestise oleh responden sebanyak 64\%. Dengan demikian pemikiran dan keyakinan mereka bahwa jiwa berwirausaha atau berbisnis akan menjadikan mereka bebas tanpa tekanan karena mereka akan menjadi bos dan tentu dihadapan masyarakat menjadikan kebanggan. Menurut BN. Marbun yang disadur dalam bukunya Buchari Alma (2007) bahwa ciri khas orang berwirausaha dan perlu dimiliki namun tidak semua memiliki adalah selalu percaya diri, berorientasi pada tugas dan hasil,pengambil resiko, kepemimpinan, keorsinalan dan berorientasi ke masa depan. Semua itu tentunya menjadi motivasi orang khususnya anak muda di
Yogyakarta selalu untuk ingin menjadi usahawan. Mereka tidak bisa diamati namun dapat disimpulkan karena adanya sesuatu perilaku yang nampak dari usaha bisnisnya yang dipajang dan dijajakan ditempattempat yang mudah dijangkau pembeli atau pelanggan atau ditawarkan di dunia maya atau internet dengan marketing on line.

Selain pendapat diatas bahwa motivasi anak muda di wilayah Yogyakarta akan dapat membantu ekonomi masyarakat dan dijawab oleh mayoritas responden sebanyak 53\% tentunya ini menarik karena sekarang pemerintah gencar-gencarnya memkampanyekan ekonomi kreatif dengan berbasis industri yang mengelola sumber daya alam dan manusia sebagai income negara selain migas dan pajak. Bukti bahwa program pemerintah itu, negara kita mulai menggalakkan dan menyebarkan pengetahuan tentang kewirausahaan secara lebih luas. Dari mulai Sekolah menengah, hingga perguruan tinggi menjadi sasaran untuk memberikan motivasi dan pengetahuan tentang pentingnya berwirausaha. Hal ini bertujuan agar saat mereka lulus dan terjun langsung ke masyarakat, mereka memiliki cukup ilmu dan mental menjadi seorang usahawan atau bisnisman. Ini bukti dari responden bahwa wirausaha merupakan cita-cita saya, karena sesuai dengan studi saya dengan jumlah responden $37,3 \%$ dan mereka akan bahagia dalam bekerja jika tidak menjadi bawaahaan orang lain dan bebas dari birokrasi yang mengikat dan bebab membuat keputusan. Inilah motivasi anak muda di wilayah Yogyakarta dengan industri kreativnya ingin menjawab tantangan bahwa dengan keputusannya mereka bisa survei dengan dunianya yaitu dengan bisnis atau berwirausaha.

\section{Pengaruh Variabel kreativitas (X1) dan Variabel motivasi (X2) Terhadap minat usaha (Y)}

Dengan regresi berganda diperoleh hasil 
bahwa kreativitas dan motivasi berpengaruh bersama-sama terhadap minat usaha dengan nilai koefisien sebesar 0.214 untuk varibel kreativitas dan 0.233 untuk variabel motivasi artinya bahwa keduanya berpengaruh positif. Dengan hasil tersebut dipastiakan bahwa baik secara sendiri maupun bersama variabel kreativitas dan variabel motivasi mempunyai pengaruh yang sangat kuat terhadap minat berwirausaha. Sebagai variabel terikat (minat berwirausaha) ternyata mempunyai pengaruh sangat kuat terhadap kedua variabel bebas (kreativitas dan motivasi berwirausaha).

Selain itu bahwa dalam variabel minat usaha (Y1) menjadikan anak muda selalu bercita-cita ingin sukses sehingga unsur-unsur dalam kreativitas dan motivasu berwirausaha menjadikan unsur pendukung. Seperti dalam pernyataan tentang memanfaatkan waktu senggang untuk melakukan kegiatan yang bermanfaat (kreativitas) dan meniti karir dibidang wirausaha lebih memberikan kepuasaan.

Berdasarkan hasil perhitungan di atas dapat disimpulkan bahwa ada hubungan yang positif antara kreativitas dan motivasi berwirausaha dengan minat berwirausaha. Menurut Yuyun Wirasasmita dalam Suryana (2003) alasan seseorang memilih berwirausaha karena:

a. Alasan keuangan, yaitu untuk mencari nafkah, untuk menjadi kaya, untuk mencari pendapatan tambahan, sebagai jaminan stabilitas keuangan.

b. Alasan sosial, yaitu untuk memperoleh gengsi/status, untuk dapat dikenal dan dihormati, untuk menjadi contoh bagi orang tua di desa, agar dapat bertemu dengan orang banyak.

c. Alasan pelayanan, yaitu untuk memberi pekerjaan pada masyarakat, untuk menatar masyarakat, untuk membantu ekonomi masyarakat, demi masa depan anak-anak dan keluarga, untuk mendapatkan kesetiaan suami/istri, untuk membahagiakan ayah dan ibu.

d. Alasan pemenuhan diri, yaitu untuk menjadi atasan/mandiri, untuk mencapai sesuatu yang diinginkan, untuk menghindari ketergantungan pada orang lain, untuk menjadi lebih produktif, dan untuk menggunakan kemampuan pribadi.

Seseorang memilih berwirausaha karena adanya kebutuhan yang harus dipenuhi. Kebutuhan manusia adalah berjenjang sesuai dengan tingkat pemenuhannya. Kebutuhan yang paling dasar adalah kebutuhan fisik. Untuk memenuhi kebutuhan fisik mengakibatkan seseorang harus bekerja agar mendapatkan penghasilan. Apabila dihadapkan dengan peluang kerja yang sempit, akan tetapi kebutuhannya harus dipenuhi, maka akan mendorong seseorang untuk mencari cara lain agar dapat memenuhi kebutuhannya. Orang yang kreatif tidak suka menggantungkan pada orang lain. Karena tidak suka bergantung pada orang lain, maka akan berpikir bagaimana cara memenuhi kebutuhannya dengan menciptakan lapangan pekerjaan baru atau dengan kata lain berwirausaha disitulah perilaku orang ketika memutuskan untuk berwirausaha karena ada dorongan dari dalam dan pengaruh dari luar yang disebut motivasi berwirausaha.

\section{Gejala Pergeseran Anak Muda Terhadap Minat Wirausaha Dengan Kreatiativitas dan Motivasi Berwiirausaha Di Yogyakarta}

Sebagai kota pendidikan, Yogyakarta penuh dengan anak-anak muda yang punya bakat terpendam dan mempunyai nilai jual jika dikembangkan atau diaplikasikan. Peran sekolah dan perguruan tinggi yang menjadi kawah candradimuka anak-anak muda akhirnya mereka mengekspresikan diri dengan membuktikan bahwa mereka bisa menjadi inovatif dari karya dan ilmunya. Dari hasil penelitian selama 2 bulan (Juli -Agustus 2014) penulis dapat membahas dan menganalisa bahwa anak- 
anak muda di wilayah Yogyakarta sudah berani mengekspresikan diri dengan karyakaryanya dimana mereka sudah berpikir untuk menjadi wirausawan. Gejala atau fenomena ini sudah mulai nampak beberapa tahun lalu dan mulai besar pengaruhnya setelah pemerintah membentuk kementrian ekonomi kreatif dimana adanya fasilitas dana dan pikiran bahwa wirausaha dapat mengatasi permasalahan bangsa.

Prosentase wirausaha di Indonesia sangat sedikit dari jumlah penduduk tidak lebih dari $10 \%$ tentunya menjadi pemikiran kita semua bahwa bangsa yang maju tentunya dipengaruhi dari besarkecilnya penduduk yang berwirausaha. Dibandingkan dengan Jepang dimana mereka jumlah penduduknya paling banyak adalah berprofesi wirausahawan sehingga ekonominya ditopang oleh usaha mereka dan ini didukung oleh faktor pemerintah yang selalu orientasinya memajukan wirausaha.

Dalam penelitian ini kami menemukan bahwa mayoritas anak muda atau responden yang didominasi anak muda di wilayah Yogyakarta mereka ingin menjadi pengusaha, bos atau usahawan entah itu usaha sendiri atau bersama orang lain dimana selalu dalam hidupnya tidak pernah puas dengan keadaan sekarang. Oleh karena tanpa mempedulikan pendidikan yang diperolah mereka punya keinginan kuat untuk berwirausaha. Mereka sudah tergambarkan seperti karakteristik utama kewirausahaan yaitu orang yang percaya diri, berorientasi pada tugas dan hasil, pengambil resiko, keorsinilan dan berorientasi pada masa depan. Semua itu artinya bahwa anak muda di Yogyakarta yang sudah punya usaha akan selalu berpegang atau berjiwa seperti yang dicirikan seperti diatas.

Dalam penelitian ini anak muda di Yogyakarta sudah mempunyai watak penuh keyakinan, ketidaktergantungan , individualitas dan optimisme. Selain itu mereka punya orientasi pada tugas dan hasil.
Dan anak muda sadar bahwa kebutuhan dalam hidup harus berprestasi, berorientasi pada laba, ketekunan dan ketabahaan, tekad kerja keras. Dan paling kuat adalah motivasi yang kuat, energik dan penuh inisiatif.

Dalam penelitian ini anak muda Yogyakarta yang kami teliti mengatakan mereka ingin bebas dari birokrasi yang mengikat dan bebas membuat keputusan bisnis artinya mereka pengambil risiko dan suka tantangan. Dengan persepsi itu mereka mempunyai kepimpinan wirausaha dimana perilakunya sebagai pemimpin , bergaul dengan orang lain serta siap dengan saran dan kritiknya. Anak muda di wilayah Yogyakarta yang sudah berwirausaha meski baru merintis ataupun sudah mapan mempunyai kemampuan menciptakan sesuatu yang baru dan berbeda dan mereka termotivasi dengan penerapan kreavitas dan inovasi dalam memecahkan persoalan dan menemukan peluang untuk memperbaiki kehidupan atau usaha.

\section{KESIMPULAN}

Berdasarkan pembahasan dari analisa data diatas, maka dapat disimpulkan sebagai berikut :

1. Kreativitas berwirausaha yang dimiliki oleh anak muda Yogyakarta sangat berpengaruh kuat pada minat usaha yaitu para anak muda yang mempunyai usaha. Selain itu juga kreativitas mereka mempunyai pengaruh yang signifikan atau mempunyai hubungan yang signifikan terhadap minat usaha untuk membuka usaha di wilayah Yogyakarta. Selain itu variabel tentang kreativitas berwirausaha tentang anak mudayang berminat dibidang usahanya ingin sesuatu yang baru. Selain itu mereka ingin mempraktekkan materi yang diperoleh dari kegiatan usahanya. Dengan demikian mereka yang terjun diusaha ingin mempelajari hal-hal yang baru karena mayoritas responden yang diteliti selalu tertarik terhadap hal-hal 
yang baru.

2. Bahwa motivasi berwirausaha yang dimiliki oleh anak muda Yogyakarta sangat berpengaruh kuat pada minat usaha yaitu para anak muda yang mempunyai usaha yang sesuai dengan kreativitas dirinya wilayah Yogyakarta artinya dorongan anak. Selain itu juga motivasi usaha mereka mempunyai pengaruh yang signifikan atau mempunyai hubungan yang signifikan terhadap minat usaha untuk membuka usaha di muda untuk membuka usaha sangat kuat karena kreativitas yang menjadi modal mereka untuk berani membuka usaha. Hasil penelitian bahwa variabel motivasi berwirausaha dari frekuensi butir -butir pernyataan yang dijawab responden bahwa dengan berwirausaha akan selalu menguntungkan. Dan mereka ingin berwirausaha karena citacita sesuai dengan studinya ternyata berwirausaha atau memiliki bisnis lebih membahagiakan daripada menjadi karyawan dan menjadikan bisnis sebagai hal prestise.Karena mereka akan menjadi bos dan tentu dihadapan masyarakat menjadikan kebanggan..

3. Berdasarkan hasil perhitungan di atas dapat disimpulkan bahwa ada hubungan yang positifantara kreativitas dan motivasi berwirausaha dengan minat berwirausaha. Hasil penelitian bahwa kreativitas dan motivasi berpengaruh bersama-sama terhadap minat usaha berwirausaha artinya keduanya berpengaruh positif. Dengan hasil tersebut dipastiakan bahwa baik secara sendiri maupun bersama variabel kreativitas dan variabel motivasi mempunyai pengaruh yang sangat kuat terhadap minat berwirausaha. Sebagai variabel terikat (minat berwirausaha) ternyata mempunyai pengaruh sangat kuat terhadap kedua variabel bebas (kreativitas dan motivasi berwirausaha).

\section{Daftar Pustaka}

Arikunto, Suharsimi. 2006. Manajemen Penelitian. Jakarta: Rineka Cipta.

Biro Pengembangan Sosial Budaya (BPSP). 2000. Membangun Ekonomi Keuangan Keluarga. Semarang.

Buletin BSI. 2008.Career Center. Vol II NO 7

Drost, J. S.J. 1993. Menjadi Pribadi Dewasa Dan Mandiri. Yogyakarta: Kanisius.

Heiddjrachman dan Husnan, S. 2002. Manajemen Personalia. Yogyakarta: BPFE

Nasution, Thamrin. 2006. Peranan Orang Tua Dalam Meningkatkan Prestasi Belajar Anak. Yogyakarta: Kanisius.

Riduwan. 2007. Metode Penelitian untuk Tesis. Bandung: Alfabeta.

Sugiono. 2004. Metodologi Penelitian Administrasi. Bandung: Alfabeta.

Sumahamijaya, Suparman. 2000. Membina Sikap Mental Wiraswasta. Jakarta: Gunung Jati.

Supardi dan Anwar,S.2004. Dasar-dasar perilaku Organisasi.Yogyakarta.UII Press

Walgito, Bimo (1989).Bimbingan dan penyuluhan di sekolah. Andi Offset Yogyakarta

Winkel, W.S. 2004. Psikologi pengajaran. Jakarta : Gramedia

Wiratmo, Masykur. 1995. Pengantar Kewiraswastaan Kerangka Dasar Memasuki Dunia Bisnis.Yogyakarta: BPFE. 
Wiriatmojo, Rochiati. 2005. Metode Penelitian. Jakarta : Rosda Karya.

Wycoff, Joyce. 2005. Menjadi Super Kreatif melalui metode Pemetaan Pikiran. Bandung : Kaifa 